\title{
REMOVAL OF TURBIDITY USING ELECTROCOAGULATION
}

\author{
Nilesh A. Fagnekar ${ }^{1}$, Sachin Mane ${ }^{2}$ \\ ${ }^{I}$ Student, D. Y. Patil College of Engineering, Akurdi, Pune, Maharashtra, India \\ ${ }^{2}$ Assistant Professor, D. Y. Patil College of Engineering, Akurdi, Pune, Maharashtra, India
}

\begin{abstract}
Electrocoagulation (EC) is a technique involving the electrolytic addition of coagulating metal ions directly from electrodes, this electrode also known as sacrificial electrode. These ions work as a coagulating agent in the water, similar manner to the addition of chemicals such as alum and ferric chloride. Electrode allows the easier removal of the turbidity. In this study experimental investigation is carried out to removal of turbidity using electrocoagulation method with the help of aluminum electrodes in a batch reactor. Several working parameters, such as $\mathrm{pH}$, current density, and operating time were varied to achieve a higher removal efficiency of turbidity. Two type of water sample were used1) synthetic turbid water and 2) back wash water synthetic water was made from crushed sand with initial turbidity of 200 NTU whereas back wash water was collected from Nigadi water treatment plant. Current intensity was varied from 2 to $6 \mathrm{~A}$. and detention time between 5 to 20 minutes with $\mathrm{pH}$ range from $\mathrm{pH}$ 3 to $\mathrm{pH}$ 11. The removal efficiencies for synthetic turbidity were found about $91 \%$ at $6 \mathrm{~A}$ for 20 minutes at neutral $\mathrm{pH}$, whereas removal efficiencies for backwash water were found about 89\% at 6A for 20 minutes at neutral pH. The results of the study indicated that the turbidity can be removed effectively by EC process using Al electrodes.
\end{abstract}

Keywords: Electrocoagulation, sacrificial electrode, Turbidity, Water Treatment

\section{INTRODUCTION}

One of the major challenges facing human today is providing clean water to a majority of the population around the world. The quantity and quality of available water are two particularly major problems facing not only the thirdworld countries but also the whole world. Rivers; lakes and other water bodies are constantly polluted due to indiscriminate discharge of industrial effluents as well as other anthropogenic activities and natural processes. Concern about water quality is related to two very important aspects: 1), contamination of drinking water or the poor quality of some sources and, 2) the quality of the treated wastewater that is discharged into fresh water bodies, leading to a problem of dispersion of pollutants. Most of the world suffers from water shortages, while in some regions, the problem are not lack of resources, but poor management and distribution of water. There are some traditional technologies being used such biological processes and physicochemical processes, which include: Filtration, ion exchange, chemical precipitation, chemical oxidation, adsorption, ultra filtration, reverse osmosis and electro dialysis, etc.[3].

The presence of particulate materials such as algae, clays, silts, organic particles and soluble substances in water often causes it to get turbid or colored. The settling ability of the particulate matter depends on the density of the material and the size of particles. The particles having density more than water should eventually settle due to gravitational force. Small particles, especially those with density close or less than to water such as bacteria and colloidal particles may never settle and remain suspended in the water. Therefore, agglomeration of particles into a larger floc is a necessary step for their removal by sedimentation [5]. Electrochemical technology helps in many ways to a cleaner environment and covers a very large range of technologies. Electrocoagulation is a simple and efficient method for the treatment of water and wastewater. It is a process in which the metal ion of the anode is released by oxidation resulting in in situ generation of coagulant [4]. Simultaneously, hydrogen gas is released at the cathode. In this process, charged ionic matter and other pollutants - are removed from water or wastewater by allowing it to react (i) with an ion having opposite charge, or (ii) with floc of metallic hydroxides generated within the effluent.

Electrocoagulation consists of pairs called electrodes, that are arranged in pairs of two one as anode, second as cathode. There are various electrochemical reactions occurring simultaneously at the electrode i.e.at anode and cathode. As current is applied, the cathode get oxidized i.e. loses its electrons, while the water get reduced i.e. gains electrons, thereby making the wastewater better treated [4]. As current is passes through a metal electrode, oxidizing the metal (M) to its cation ( $\mathrm{Mn}+)$ as shown in equation (1). Simultaneously, water is reduced to hydrogen gas and the form hydroxyl ion (OH-) as shown in equation (2). Electrodes are known to be sacrificed for the release of metal ions at the anode, were cathode is responsible to produce hydroxyl ions. Metallic electrodes release its electron to produce ions in the water which ultimately neutralized the charges of suspended particles leading to coagulation. The generated cations help by diminishing the stability of the suspended partials, by decreasing their zeta potential. Also, upon formation of hydroxide ions at the cathode, metal ions react with hydroxide ions and form aluminum hydroxides, which are known to be efficient coagulants. The released ions remove suspended solids by precipitation or flotation. EC caused ionization of the water molecules adhering the suspended solids to convert them 
into insoluble flock to be sediment under gravity or float depending on density.

The reactions at the anode and cathode are respectively:

$$
\begin{array}{r}
\mathrm{M} \rightarrow \mathrm{Mn}++ \text { ne- } \ldots . \\
2 \mathrm{H} 2 \mathrm{O}+2 \mathrm{e}-\rightarrow 2 \mathrm{OH}-+\mathrm{H} 2
\end{array}
$$

So that;

$$
\mathrm{AI}-3 \mathrm{e}-\rightarrow \mathrm{AI} 3+
$$

Reactions forms may accrue as follows:

$$
\begin{aligned}
\mathrm{O} 2+2 \mathrm{H} 2 \mathrm{O}+4 \mathrm{e}- & \rightarrow 4 \mathrm{OH}- \\
\mathrm{O} 2+4 \mathrm{H}++4 \mathrm{e}- & \rightarrow 2 \mathrm{H} 2 \mathrm{O} . \\
2 \mathrm{H}++2 \mathrm{e}- & \rightarrow \mathrm{H} 2 \ldots \ldots
\end{aligned}
$$

\subsection{Turbid Water Preparation}

In this Experiment the sample was collected from crushed sand. The collected samples were sieved and the fractions below $75 \mu \mathrm{m}$ mesh was used for the study. The turbid sample was prepared by mixing 7 to 8 grams of the below $75 \mu \mathrm{m}$ mesh crushed fraction in $2000 \mathrm{ml}$ water. Turbidity in samples was measured before and after electrocoagulation by using the turbidity meter.

\subsection{Back Wash Water Sample}

In this Experiment the Back wash sample was collected from filtration unit of water treatment plant of Nigadi water treatment plant. Sample was collected after 5 minute of back wash. Turbidity of samples is measured with the help the Nephelometric Turbidity Unit (NTU).

\subsection{Experimental Setup}

In these experiments, the electrochemical cell consisted of a 2000-ml container and two series electrodes. Aluminum electrodes $(15.0 \times 5.1 \mathrm{~cm})$ were used as electrodes and reaction area of about $(3.8 \times 5.1) \mathrm{cm}$ were used. They were treated with the solution of $\mathrm{HCl}$ for cleaning prior to use. The container was filled with $2000 \mathrm{ml}$ of sample turbid water and the electrode plates were held suspended $4 \mathrm{~cm}$ apart in the water. The anode was connected with an ammeter and rheostat and it was used to examine the current flow and regulate the flow of electricity respectively. The anode was weighted before and after the experiment for each run to estimate the electrode consumption. All experiments were conducted at normal room temperature. The experimental Setup as shown in fig. 1

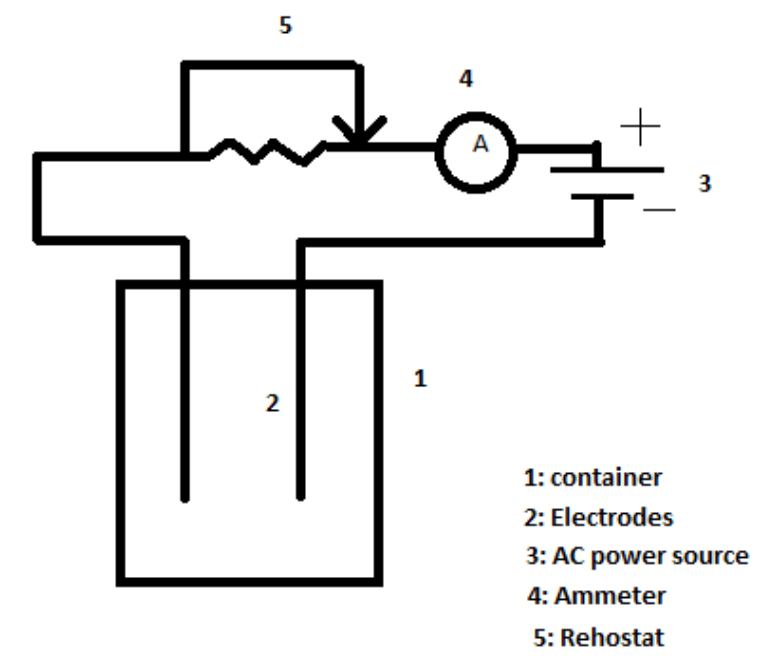

Fig -1: line diagram of Experimental setup

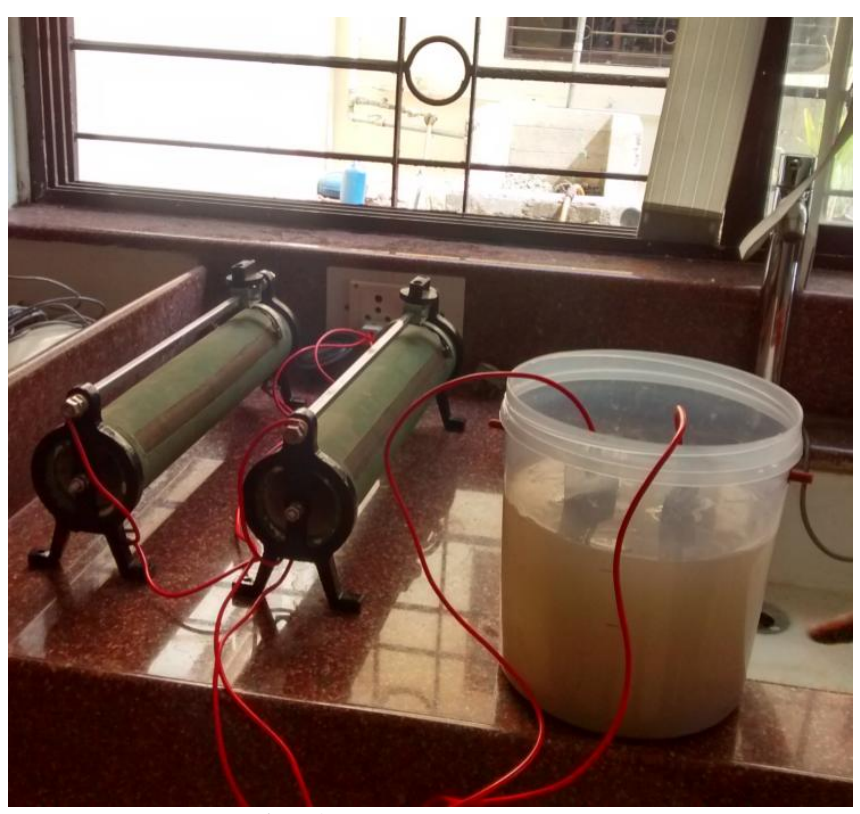

Fig -2: Experimental setup

\section{RESULT}

The effects of some parameters such as applied current, reaction time and $\mathrm{pH}$ have been evaluated in this experiment. The result of test conducted as shown below Removal efficiency is calculated from formula

$$
\% \text { removal }=\left\{\frac{\mathrm{Co}-\mathrm{C} 1}{\mathrm{Co}}\right\} * 100
$$

Where,

C0 is initial Turbidity,

$\mathrm{C} 1$ is final Turbidity

\subsection{Synthetic Water Sample Result}

Below table shows removal efficiencies of synthetic turbid water at $2 \mathrm{~A}$ current intensity, and $\mathrm{pH}$ values of 5, 7.5, 9 and reaction time of 5, 10 and 20 minutes. Removal efficiency is 
higher i.e. $86 \%$ at neutral $\mathrm{pH}$ keeping current intensity $2 \mathrm{~A}$ and reaction time of 20 minutes.

Table -1: Result for 2A current

\begin{tabular}{|l|l|l|l|l|l|}
\hline $\begin{array}{l}\text { Sr } \\
\text { no }\end{array}$ & $\mathrm{pH}$ & $\begin{array}{l}\text { Time for } \\
\text { treatment } \\
(\mathrm{min})\end{array}$ & $\begin{array}{l}\text { Initial } \\
\text { turbidity } \\
(\mathrm{NTU})\end{array}$ & $\begin{array}{l}\text { Final } \\
\text { turbidity } \\
(\mathrm{NTU})\end{array}$ & $\begin{array}{l}\text { Removal } \\
\text { efficiency } \\
\%\end{array}$ \\
\hline 1 & 5.00 & 5 & 189 & 92 & 51.32 \\
\hline 2 & 5.00 & 10 & 200 & 57 & 71.50 \\
\hline 3 & 5.00 & 15 & 209 & 37 & 82.30 \\
\hline 4 & 5.00 & 20 & 201 & 33 & 83.58 \\
\hline 5 & 7.50 & 5 & 202 & 97 & 51.98 \\
\hline 6 & 7.50 & 10 & 203 & 54 & 73.40 \\
\hline 7 & 7.50 & 15 & 197 & 29 & 85.28 \\
\hline 8 & 7.50 & 20 & 203 & 28 & 86.21 \\
\hline 9 & 9.00 & 5 & 207 & 102 & 50.72 \\
\hline 10 & 9.00 & 10 & 215 & 69 & 67.91 \\
\hline 11 & 9.00 & 15 & 205 & 44 & 78.54 \\
\hline 12 & 9.00 & 20 & 201 & 38 & 81.09 \\
\hline
\end{tabular}

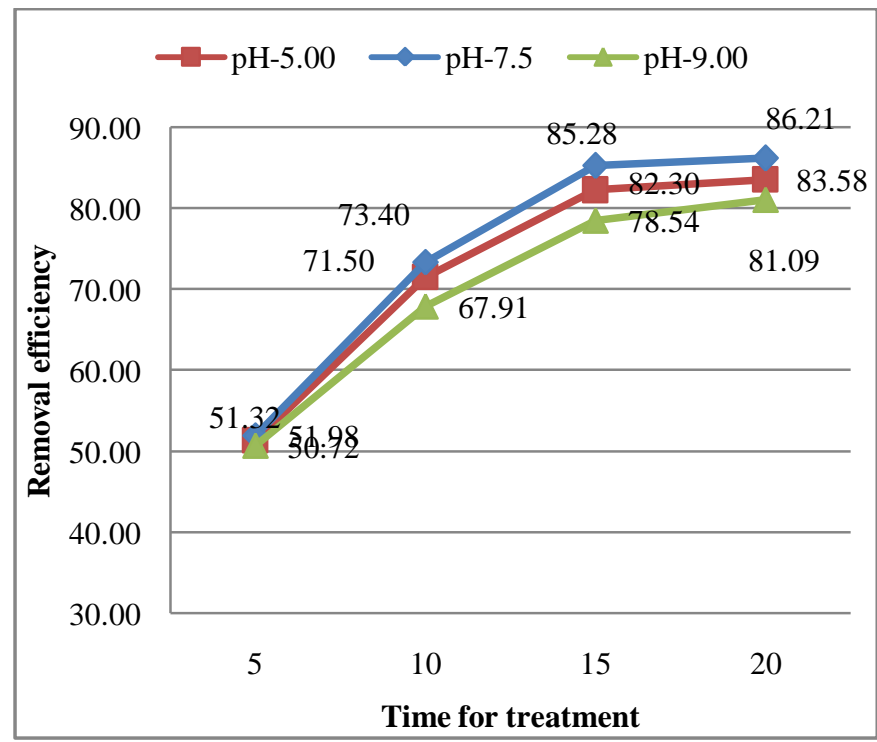

Graph 1: Time optimization for turbidity removal for $2 \mathrm{~A}$ current

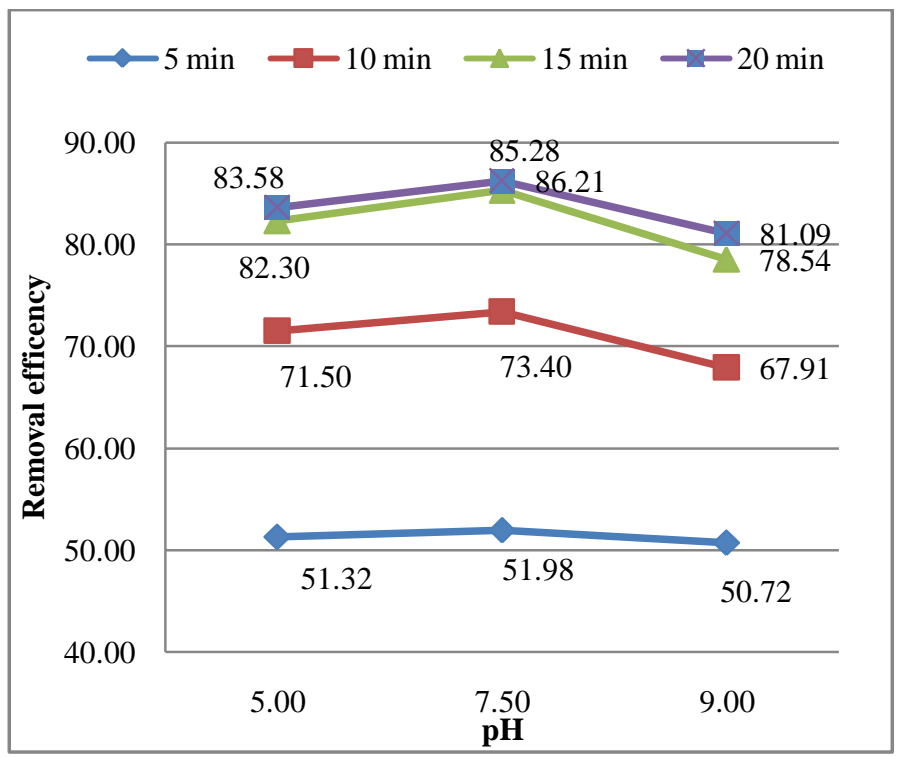

Graph 2: pH optimization for turbidity removal for 2A current

Below table shows removal efficiencies of synthetic turbid water at 4A current intensity, and $\mathrm{pH}$ values of 5, 7.5, 9 and reaction time of 5, 10 and 20 minutes. Removal efficiency is higher i.e. $91 \%$ at neutral $\mathrm{pH}$ keeping current intensity $4 \mathrm{~A}$ and reaction time of 20 minutes.

Table -2: Result for 4A current

\begin{tabular}{|l|l|l|l|l|l|}
\hline $\begin{array}{l}\text { Sr } \\
\text { no }\end{array}$ & $\mathrm{pH}$ & $\begin{array}{l}\text { Time for } \\
\text { treatment } \\
(\mathrm{min})\end{array}$ & $\begin{array}{l}\text { Initial } \\
\text { turbidity } \\
(\mathrm{NTU})\end{array}$ & $\begin{array}{l}\text { Final } \\
\text { turbidity } \\
(\mathrm{NTU})\end{array}$ & $\begin{array}{l}\text { Removal } \\
\text { efficiency } \\
\%\end{array}$ \\
\hline 1 & 5 & 5 & 209 & 89 & 57.42 \\
\hline 2 & 5 & 10 & 202 & 58 & 71.29 \\
\hline 3 & 5 & 15 & 198 & 30 & 84.85 \\
\hline 4 & 5 & 20 & 202 & 27 & 86.63 \\
\hline 5 & 7.5 & 5 & 198 & 80 & 59.6 \\
\hline 6 & 7.5 & 10 & 207 & 50 & 75.85 \\
\hline 7 & 7.5 & 15 & 212 & 22 & 89.62 \\
\hline 8 & 7.5 & 20 & 205 & 18 & 91.22 \\
\hline 9 & 9 & 5 & 203 & 90 & 55.67 \\
\hline 10 & 9 & 10 & 206 & 60 & 70.87 \\
\hline 11 & 9 & 15 & 199 & 34 & 82.91 \\
\hline 12 & 9 & 20 & 195 & 31 & 84.1 \\
\hline
\end{tabular}




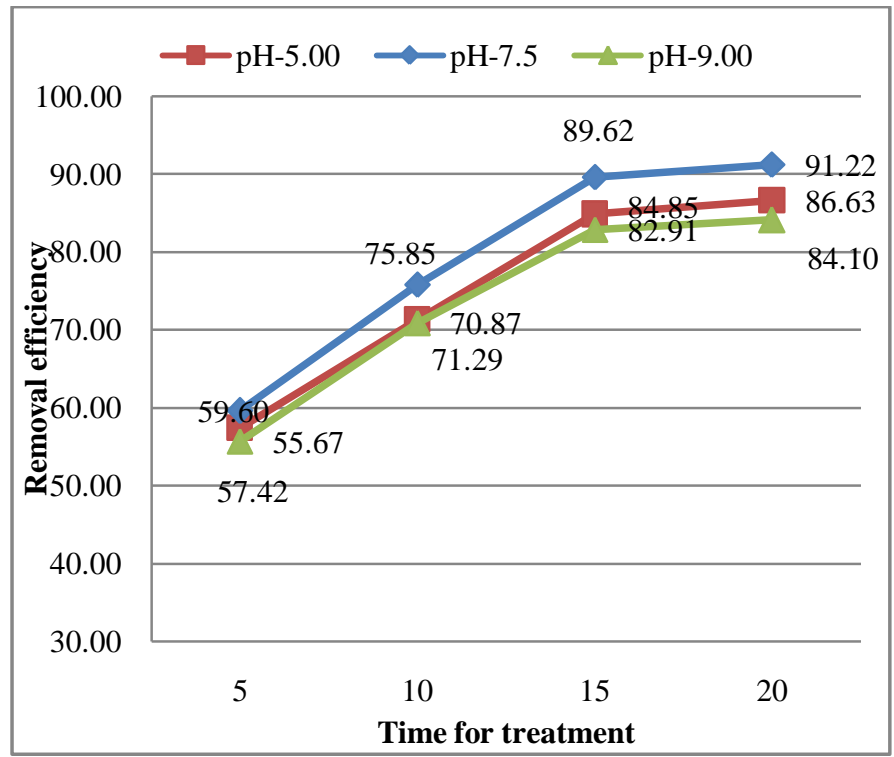

Graph 3: Time optimization for turbidity removal for 4A current

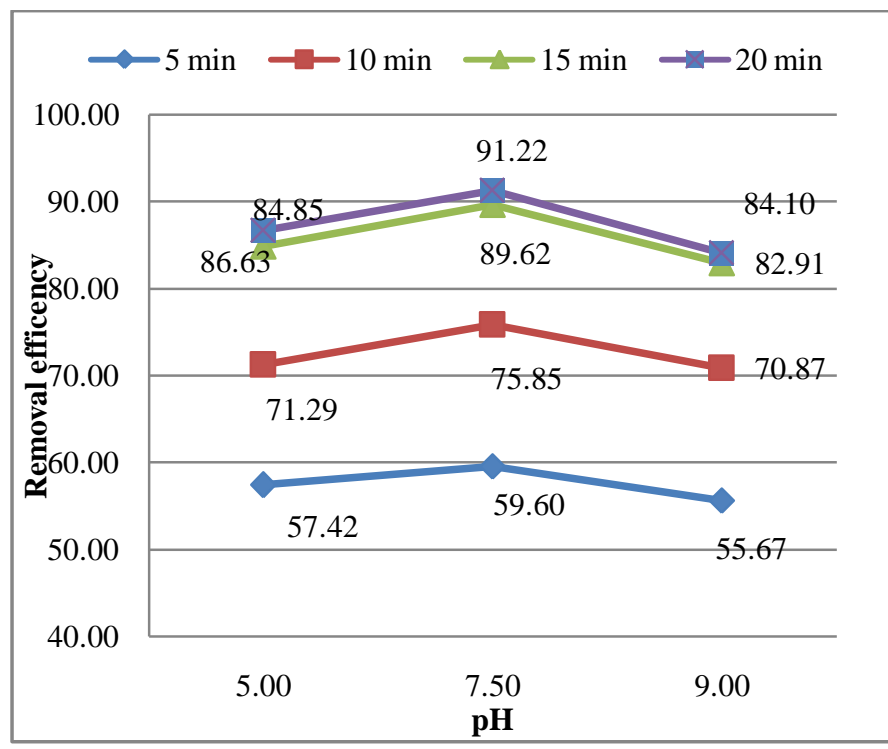

Graph 4: pH optimization for turbidity removal for 4A current

Below table shows removal efficiencies of synthetic turbid water at $6 \mathrm{~A}$ current intensity, and $\mathrm{pH}$ values of 5, 7.5, 9 and reaction time of 5, 10 and 20 minutes. Removal efficiency is higher i.e. $91 \%$ at neutral $\mathrm{pH}$ keeping current intensity $6 \mathrm{~A}$ and reaction time of 20 minutes.

Table -2: Result for 6A current

\begin{tabular}{|l|l|l|l|l|l|}
\hline $\begin{array}{l}\text { Sr } \\
\text { no }\end{array}$ & $\mathrm{pH}$ & $\begin{array}{l}\text { Time for } \\
\text { treatment } \\
(\mathrm{min})\end{array}$ & $\begin{array}{l}\text { Initial } \\
\text { turbidity } \\
(\mathrm{NTU})\end{array}$ & $\begin{array}{l}\text { Final } \\
\text { turbidity } \\
\text { (NTU) }\end{array}$ & $\begin{array}{l}\text { Removal } \\
\text { efficiency } \\
\%\end{array}$ \\
\hline 1 & 5.00 & 5 & 203 & 89 & 56.16 \\
\hline 2 & 5.00 & 10 & 205 & 54 & 73.66 \\
\hline 3 & 5.00 & 15 & 200 & 26 & 87.00 \\
\hline 4 & 5.00 & 20 & 202 & 24 & 88.12 \\
\hline
\end{tabular}

\begin{tabular}{|l|l|l|l|l|l|}
5 & 7.50 & 5 & 195 & 77 & 60.51 \\
\hline 6 & 7.50 & 10 & 205 & 48 & 76.59 \\
\hline 7 & 7.50 & 15 & 202 & 19 & 90.59 \\
\hline 8 & 7.50 & 20 & 209 & 18 & 91.39 \\
\hline 9 & 9.00 & 5 & 197 & 88 & 55.33 \\
\hline 10 & 9.00 & 10 & 194 & 55 & 71.65 \\
\hline 11 & 9.00 & 15 & 199 & 29 & 85.43 \\
\hline 12 & 9.00 & 20 & 205 & 27 & 86.83 \\
\hline
\end{tabular}

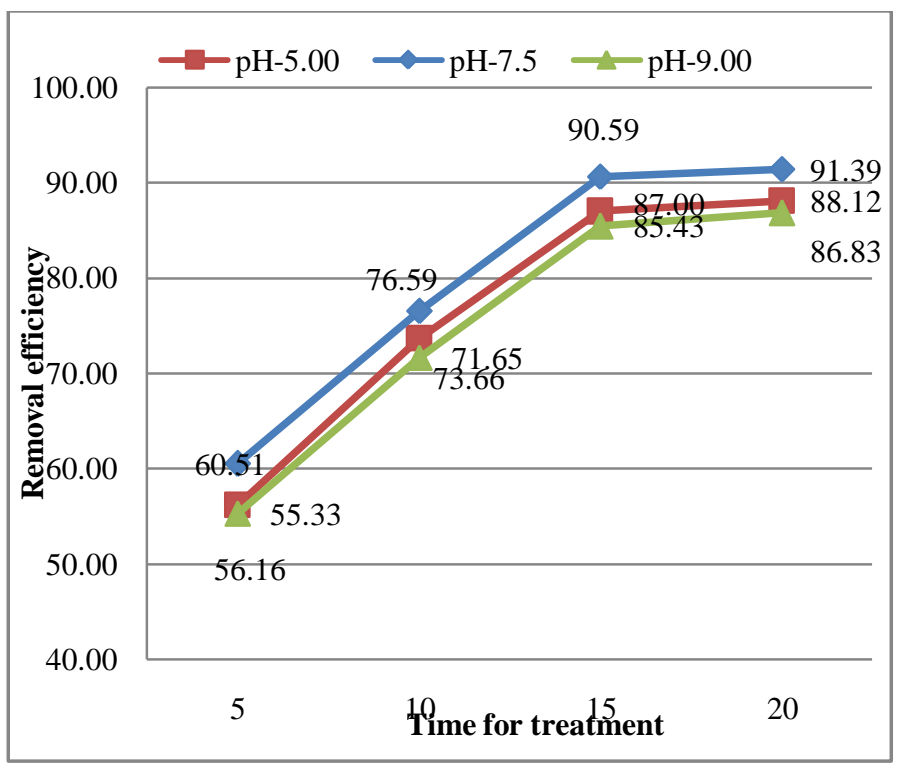

Graph 5: Time optimization for turbidity removal for 4A current

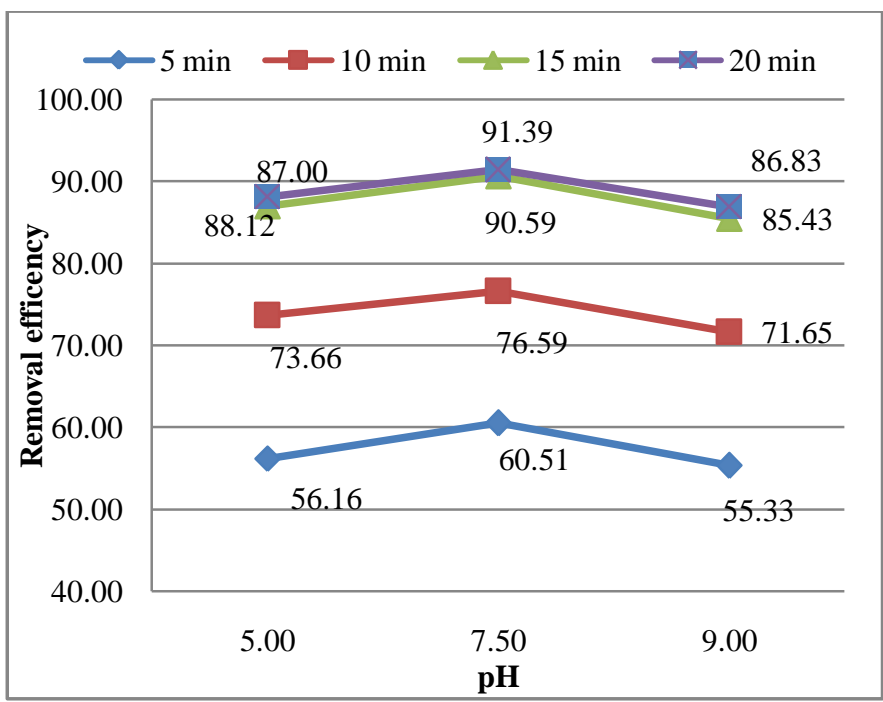

Graph 6: $\mathrm{pH}$ optimization for turbidity removal for 6A current

\subsection{Back Wash Water Sample Result}

Below Table shows removal efficiencies of back wash turbid water at $2 \mathrm{~A}$ current intensity, and $\mathrm{pH}$ values of 5, 7.5, 9 and reaction time of 5,10 and 20 minutes. Removal efficiency is higher i.e. $84 \%$ at neutral $\mathrm{pH}$ keeping current intensity $2 \mathrm{~A}$ and reaction time of 20 minutes. 
Table -4: Result for 2A current (Back wash water)

\begin{tabular}{|l|l|l|l|l|l|}
\hline $\begin{array}{l}\text { Sr } \\
\text { no }\end{array}$ & $\mathrm{pH}$ & $\begin{array}{l}\text { Time for } \\
\text { treatment } \\
(\mathrm{min})\end{array}$ & $\begin{array}{l}\text { Initial } \\
\text { turbidity } \\
(\mathrm{NTU})\end{array}$ & $\begin{array}{l}\text { Final } \\
\text { turbidity } \\
\text { (NTU) }\end{array}$ & $\begin{array}{l}\text { Removal } \\
\text { efficiency } \\
\%\end{array}$ \\
\hline 1 & 5.00 & 5 & 409 & 201 & 50.86 \\
\hline 2 & 5.00 & 10 & 417 & 151 & 63.79 \\
\hline 3 & 5.00 & 15 & 398 & 81 & 79.65 \\
\hline 4 & 5.00 & 20 & 420 & 78 & 81.43 \\
\hline 5 & 7.50 & 5 & 427 & 188 & 55.97 \\
\hline 6 & 7.50 & 10 & 411 & 119 & 71.05 \\
\hline 7 & 7.50 & 15 & 413 & 73 & 82.32 \\
\hline 8 & 7.50 & 20 & 430 & 68 & 84.19 \\
\hline 9 & 9.00 & 5 & 433 & 209 & 51.73 \\
\hline 10 & 9.00 & 10 & 451 & 158 & 64.97 \\
\hline 11 & 9.00 & 15 & 421 & 83 & 80.29 \\
\hline 12 & 9.00 & 20 & 418 & 74 & 82.30 \\
\hline
\end{tabular}

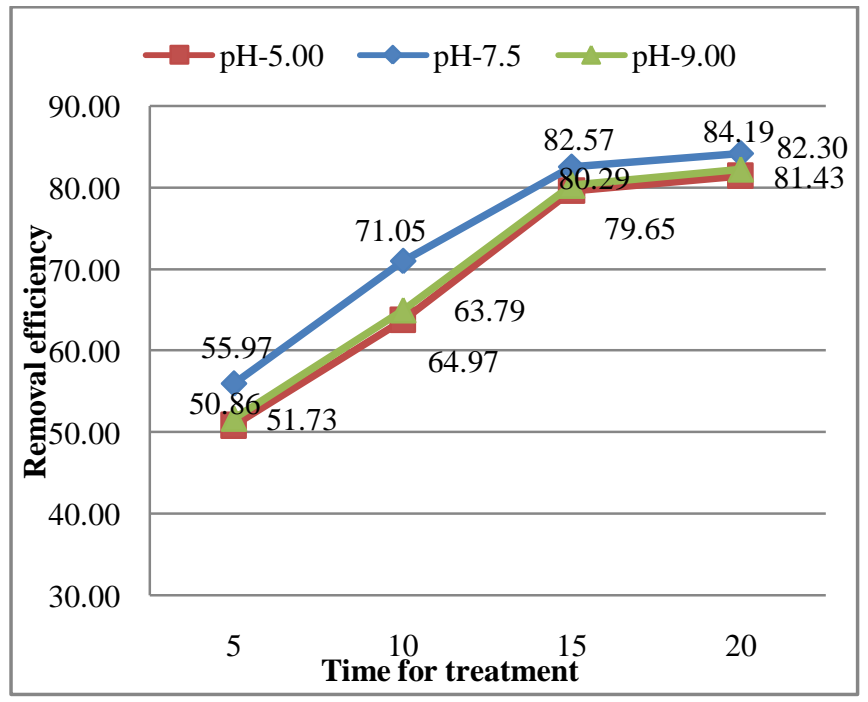

Graph 7: Time optimization for turbidity removal for 2A current (Back wash water)

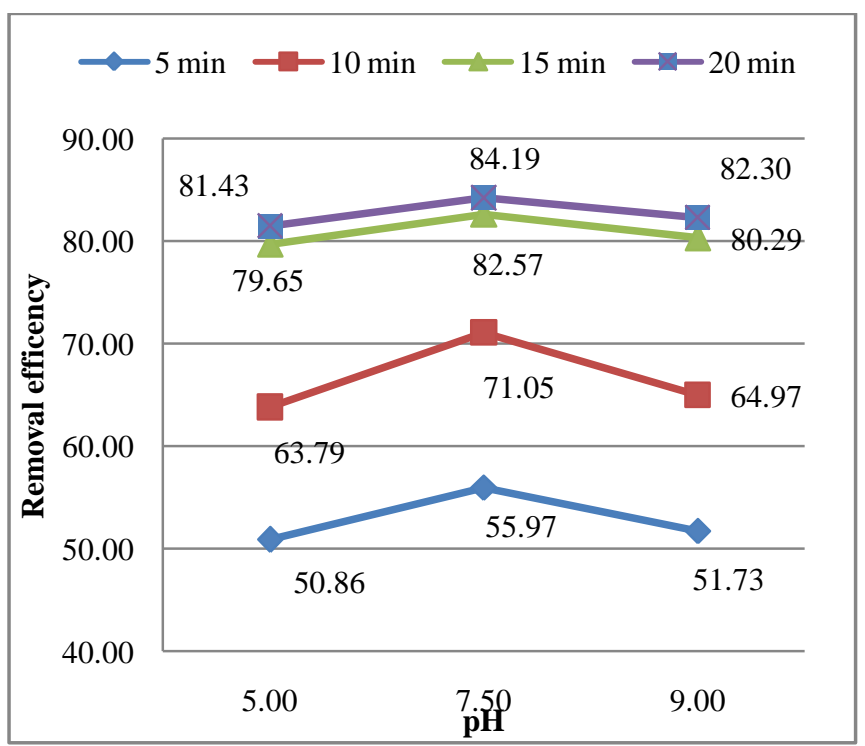

Graph 8: $\mathrm{pH}$ optimization for turbidity removal for $2 \mathrm{~A}$ current (Back wash water)

Below table shows removal efficiencies of back wash turbid water at $4 \mathrm{~A}$ current intensity, and $\mathrm{pH}$ values of $5,7.5,9$ and reaction time of 5, 10 and 20 minutes. Removal efficiency is higher i.e. $88 \%$ at neutral $\mathrm{pH}$ keeping current intensity $4 \mathrm{~A}$ and reaction time of 20 minutes

Table -5: Result for 4A current (Back wash water)

\begin{tabular}{|l|l|l|l|l|l|}
\hline $\begin{array}{l}\text { Sr } \\
\text { no }\end{array}$ & $\mathrm{pH}$ & $\begin{array}{l}\text { Time for } \\
\text { treatment } \\
(\mathrm{min})\end{array}$ & $\begin{array}{l}\text { Initial } \\
\text { turbidity } \\
(\mathrm{NTU})\end{array}$ & $\begin{array}{l}\text { Final } \\
\text { turbidity } \\
\text { (NTU) }\end{array}$ & $\begin{array}{l}\text { Removal } \\
\text { efficiency } \\
\%\end{array}$ \\
\hline 1 & 5.00 & 5 & 389 & 187 & 51.93 \\
\hline 2 & 5.00 & 10 & 385 & 122 & 68.31 \\
\hline 3 & 5.00 & 15 & 399 & 67 & 83.21 \\
\hline 4 & 5.00 & 20 & 403 & 66 & 83.62 \\
\hline 5 & 7.50 & 5 & 397 & 171 & 56.93 \\
\hline 6 & 7.50 & 10 & 391 & 113 & 71.10 \\
\hline 7 & 7.50 & 15 & 419 & 57 & 86.40 \\
\hline 8 & 7.50 & 20 & 447 & 51 & 88.59 \\
\hline 9 & 9.00 & 5 & 441 & 209 & 52.61 \\
\hline 10 & 9.00 & 10 & 398 & 139 & 65.08 \\
\hline 11 & 9.00 & 15 & 422 & 69 & 83.65 \\
\hline 12 & 9.00 & 20 & 411 & 73 & 82.24 \\
\hline
\end{tabular}

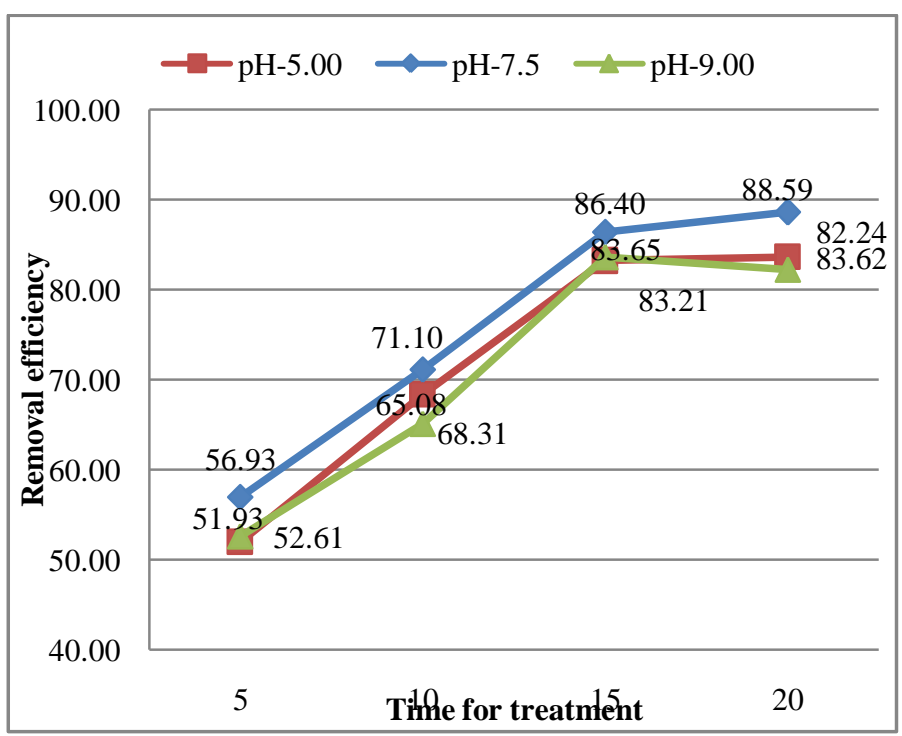

Graph 9: Time optimization for turbidity removal for 4A current (Back wash water) 


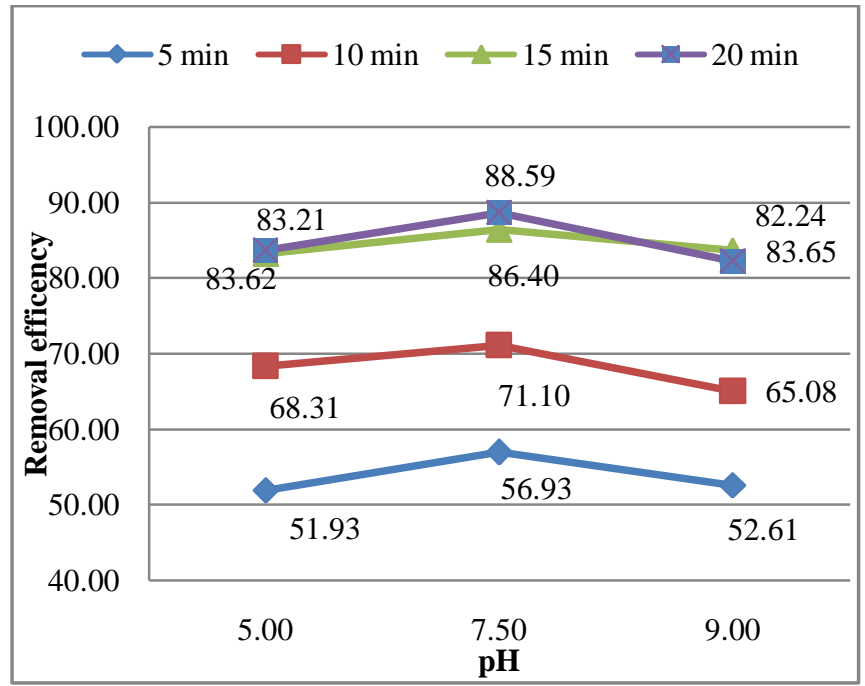

Graph 10: $\mathrm{pH}$ optimization for turbidity removal for $4 \mathrm{~A}$ current (Back wash water)

Below table shows removal efficiencies of back wash turbid water at $6 \mathrm{~A}$ current intensity, and $\mathrm{pH}$ values of 5, 7.5, 9 and reaction time of 5, 10 and 20 minutes. Removal efficiency is higher i.e. $89 \%$ at neutral $\mathrm{pH}$ keeping current intensity $6 \mathrm{~A}$ and reaction time of 20 minutes.

Table -6: Result for 6A current (Back wash water)

\begin{tabular}{|l|l|l|l|l|l|}
\hline $\begin{array}{l}\text { Sr } \\
\text { no }\end{array}$ & $\mathrm{pH}$ & $\begin{array}{l}\text { Time for } \\
\text { treatment } \\
(\mathrm{min})\end{array}$ & $\begin{array}{l}\text { Initial } \\
\text { turbidity } \\
(\mathrm{NTU})\end{array}$ & $\begin{array}{l}\text { Final } \\
\text { turbidity } \\
\text { (NTU) }\end{array}$ & $\begin{array}{l}\text { Removal } \\
\text { efficiency } \\
\%\end{array}$ \\
\hline 1 & 5.00 & 5 & 427 & 200 & 53.16 \\
\hline 2 & 5.00 & 10 & 439 & 130 & 70.39 \\
\hline 3 & 5.00 & 15 & 421 & 63 & 85.04 \\
\hline 4 & 5.00 & 20 & 424 & 60 & 85.85 \\
\hline 5 & 7.50 & 5 & 415 & 173 & 58.31 \\
\hline 6 & 7.50 & 10 & 412 & 108 & 73.79 \\
\hline 7 & 7.50 & 15 & 404 & 51 & 87.38 \\
\hline 8 & 7.50 & 20 & 429 & 47 & 89.04 \\
\hline 9 & 9.00 & 5 & 423 & 208 & 50.83 \\
\hline 10 & 9.00 & 10 & 403 & 126 & 68.73 \\
\hline 11 & 9.00 & 15 & 395 & 70 & 82.28 \\
\hline 12 & 9.00 & 20 & 396 & 64 & 83.84 \\
\hline
\end{tabular}

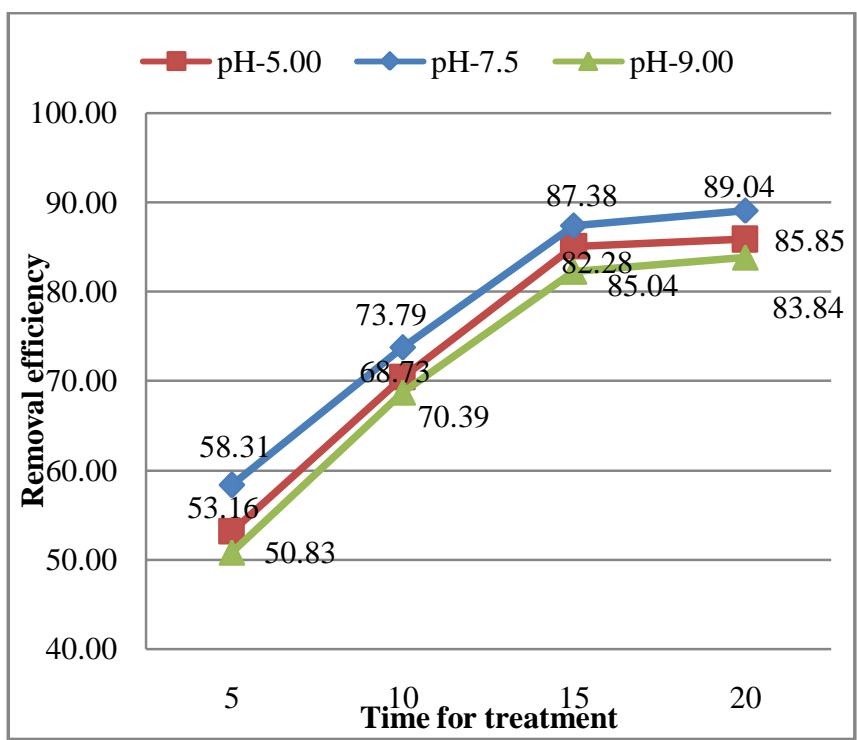

Graph 11: Time optimization for turbidity removal for $6 \mathrm{~A}$ current (Back wash water)

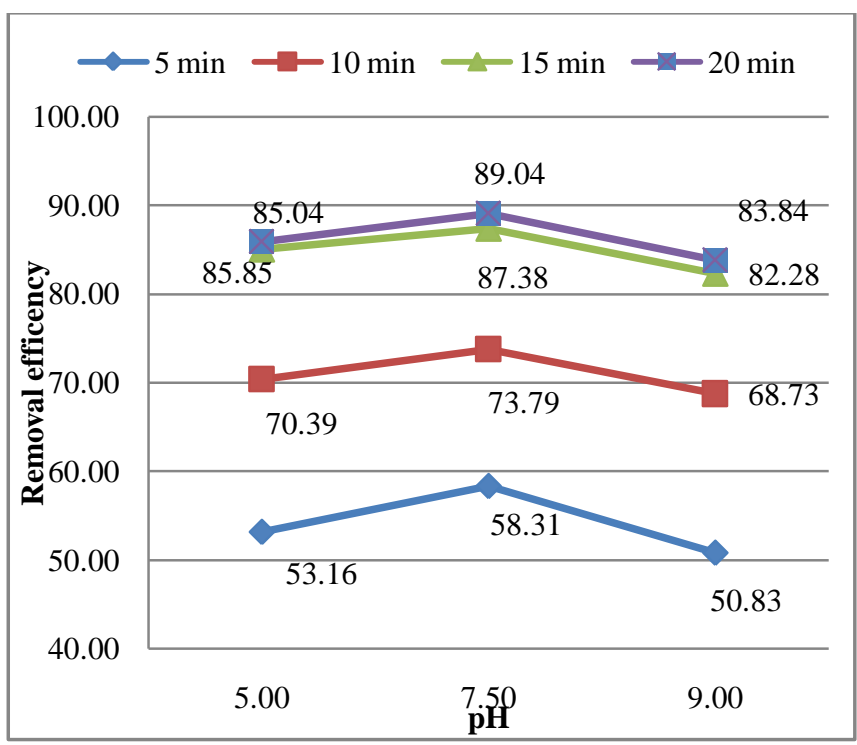

Graph 12: $\mathrm{pH}$ optimization for turbidity removal for 6A current (Back wash water)

\subsubsection{Effect of pH on Electrocoagulation}

Since the $\mathrm{pH}$ of solution plays an important role in treatment of water. In this study the effect of $\mathrm{pH}$ in the range of 5 to 9 was investigated. In electrocoagulation it is observed that neutral $\mathrm{pH}$ and slightly acidic $\mathrm{pH}$ was found to be better for turbidity reduction. As we seen in above graph, highest removal efficiency was found at neutral $\mathrm{pH}$ at different current intensity and time interval.

\subsubsection{Effect of Time on Electrocoagulation}

Above graphs shows the effect of electrolysis time on $\%$ turbidity removal at different time intervals. The $\%$ turbidity removal increases rapidly to reach about 52 to $91 \%$ in 20 minutes then it approaches almost a constant removal rate. During the experiment the effect of electrolysis time on the removal of turbidity using EC at different $\mathrm{pH}$ values (5.0, 7.0 and 9.0) was studied and analyzed at different current 
intensity of 2, 4 and 6. It is observed that maximum removal efficiency was obtained at 20 minutes of reaction time at $6 \mathrm{~A}$ current at $\mathrm{pH} 7.5$.

\subsubsection{Effect of applied Current Intensity on}

\section{Electrocoagulation}

One of the most important parameter influencing the performance and economy of the electrocoagulation process is the applied current at the electrodes. To understand the effect of applied current intensity on the removal efficiency of electrocoagulation process in treating of synthetic turbid water and back wash water, several current intensity in the range of $2 \mathrm{~A}$ to $6 \mathrm{~A}$ were applied between the electrodes in the electrocoagulation cell, and turbidity removal was determined.. The \% turbidity removal increases rapidly increases with applied current the highest removal efficiency was found at $6 \mathrm{~A}$ for 20 minutes of treatment as shown in above table.

\section{CONCLUSION}

It was shown that the efficiency of water turbidity removal was depended significantly on the applied current intensity, electrolysis time and $\mathrm{pH}$ of water .Turbidity removal by EC for synthetic sample was up to $92 \%$ at 20 min-6Awhen $\mathrm{pH}$ is neutral and to $91 \%$ at $20 \mathrm{~min}-4 \mathrm{~A}$ for $\mathrm{pH}$ neutral and to $86 \%$ at $20 \mathrm{~min}-2 \mathrm{~A}$ for neutral solution respectively. Results taken from the Experiment under acidic, basic and neutral conditions showed that neutral $\mathrm{pH}$ condition is more effective in removal of turbidity. Similarly for back wash removal by EC was up to $89 \%$ at 20 min-6Awhen $\mathrm{pH}$ is neutral and to $88 \%$ at $20 \mathrm{~min}-4 \mathrm{~A}$ for $\mathrm{pH}$ neutral and to $84 \%$ at $20 \mathrm{~min}-2 \mathrm{~A}$ for neutral solution. When the effect of time in electrocoagulation process was investigated, the turbidity removal rates were in maximum level in $20 \mathrm{~min}$ minutes.

\section{REFERENCES}

[1] Reference 1 S. Perez-Sicairos, J.B. Morales-Cuevas, J.B Morals-Cuevas, R.M.Felix-Navarrro, and O.M. Hernandez-calderon (2011) "Evaluation of the electrocoagulation process for the removal of turbidity of river water, wastewater and pond water" vol. 10, no. 1 (2011) page no: 79-91

[2] S. M. N. Islam S. H. Rahman, M. M. Rahman, T. M. Adyel, R. A. Yesmin, M. S. Ahmed, and N. Kaiser "Excessive Turbidity Removal from Textile Effluents Using Electrocoagulation Technique" J. Sci. Res. Vol (3), page no557-568

[3] Moh Faiqun Ni'am, Fadil Othman, Johan Sohaili, Zulfa Fauzia (2007) "Removal Of Cod And Turbidity To Improve Wastewater Quality Using Electrocoagulation Technique" The Malaysian Journal of Snalytical Sciences vol. 11 page no 198-205

[4] Sekman, E., Top, S., Uslu, E., Varank, G. and Bilgili, M. S.* "Treatment of Oily Wastewater from Port Waste Reception Facilities by Electrocoagulation” Int. J. Environ. Res., vol. 5(4): page no: 1079-1086
[5] Kubra Ulucan, Harun Akif Kabuk, Fatih Ilhan, Ugur Kurt "Electrocoagulation Process Application in Bilge Water Treatment Using Response Surface Methodology" Int. J. Electrochem. Sci., vol no 9, page no $2316-2326$.

[6] Deepak sharma "Treatment of dairy waste water by electrocoagulation using aluminum electrodes and settling, filtration studies" International Journal of Chemtech Research, vol no. 6 page no 591- 599.

\section{BIOGRAPHIES}

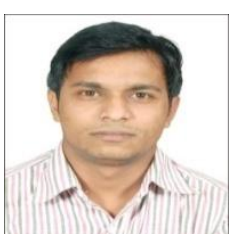

Nilesh Avinash Fagnekar, Completed B.tech in Civil Engineering from Maharashtra institute of technology , Aurangabad, Maharashtra

Pursuing Master's degree in Environmental Engineering from D.Y Patil collage of Engineering Akurdi, Pune, Maharashtra

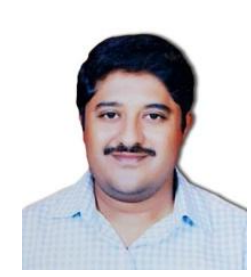

Sachin Mane, Assistant Professor, D. Y. Patil College of Engineering, Akurdi, Pune, Maharashtra, India 